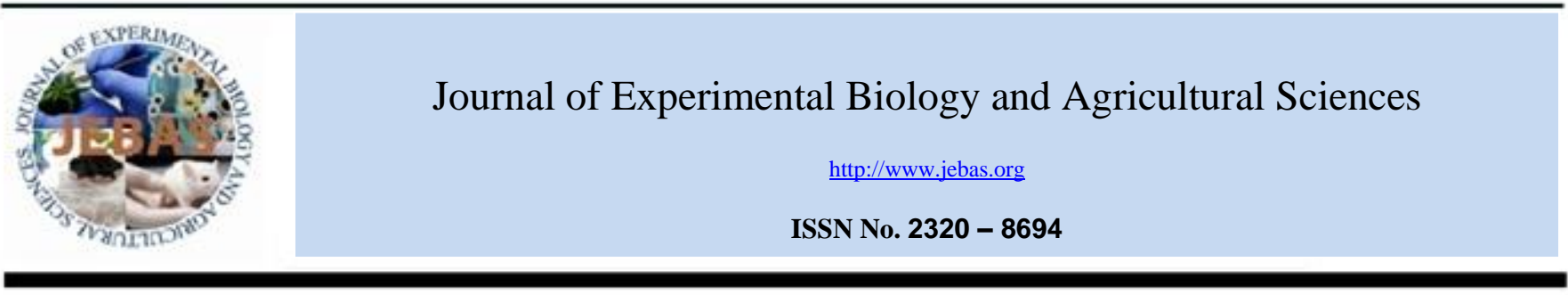

\title{
REORIENTING DAIRY EXTENSION TO MEET CHANGING NEEDS OF SMALLHOLDER DAIRY PRODUCTION SYSTEM
}

\author{
N K Sudeep kumar ${ }^{1, *}$ and D Thirunavukkarasu ${ }^{2}$
}

${ }^{1}$ Director, Directorate of Extension Education, Tamil Nadu Veterinary and Animal Sciences University, Chennai 600051 Tamil Nadu

${ }^{2}$ Assistant Professor, Department of Veterinary and Animal Husbandry Extension Education, Veterinary College and Research Institute, Namakkal, Tamil Nadu

Received - August 08, 2016; Revision - September 28, 2016; Accepted - October 08, 2016

Available Online - October 13, 2016

DOI: http://dx.doi.org/10.18006/2016.4(Spl-2-SSPN).S17.S22

\section{KEYWORDS \\ Smallholder dairy \\ Dairy extension \\ Research in extension}

\begin{abstract}
In the context of neo liberal policies Indian smallholder dairy farming is undergoing changes in milk processing, marketing, livestock services delivery, changing profile of producers and interaction between crop and dairy animals. On other side increasing urbanization accelerates demand for milk and milk products and sets up pressure on at production level. This may result in emergence of moderate intensive farms with part time farmers who are more likely to be of women. This necessitates reorientation of dairy extension system and extension research. Dairy extension system needs to meet out increasing demand of knowledge for moderate intensive farms. While research in extension taken up to develop an extension strategies to meet out the challenges of emerging farming patterns; climate change; environment concerns and research delivery pathways.
\end{abstract}

* Corresponding author

E-mail: sudeep66@hotmail.com(N K Sudeepkumar)

Peer review under responsibility of Journal of Experimental Biology and Agricultural Sciences.

Production and Hosting by Horizon Publisher India [HPI] (http://www.horizonpublisherindia.in/).

All rights reserved.
All the article published by Journal of Experimental Biology and Agricultural Sciences is licensed under a Creative Commons Attribution-NonCommercial 4.0 International License Based on a work at www.jebas.org.

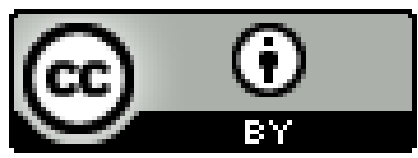




\section{Introduction}

Livestock production especially dairying is vital to economies of developing countries. For resource poor farmers, dairying is a source of wealth as it provides milk, draught power, including transport and organic fertilizer. The sustenance of rural livelihood especially among those who own dairy animals more at stake than earlier. Smallholder dairying is shrinking in general and more so in regions where resources are poor. In spite of such trend, dairying in India continues to have a larger share in livestock sector.

This is due to the fact that more than 50 per cent of world's buffalo and 20 per cent of cattle are from India. However, livestock sectors net contribution to national economy from 1980 to 2010 has steadily declined (GOI, Planning Commission, 2012). The contribution of livestock sector to the national GDP is 3.9 per cent in which dairying accounts to a major share. Large share of livestock contribution to GDP is from dairying. This is in line with overall trend of declining agriculture contribution to national Gross Domestic Product (GDP) from 30 per cent to 14 per cent with the surge of contribution of non farm sector over the last 25 years. At the same time compounded annual growth of dairy sector is 15 to 17 per cent.

The importance of dairying in economic development is beyond its contribution to the growth in national income with improved livelihood, providing nutrition to increasing population. Dairying is a subsidiary occupation to rural poor especially landless and casually employed farm labourers, small and marginal farmers and among women who take lead to manage and produce milk. Most poor in India live in rural areas, thus dairying has a key role in reduction poverty, achieving one of the United Nation millennium development goals namely reduction of poverty.

The need for dairy production is increasing and it is important to sustain smallholder dairy producers, since they are resource poor and there is need to cater to their welfare. Human capitals in the form of knowledge on scientific dairying and skills have to be promoted. Dissemination of timely market information and providing links between producers and processors or producer groups for processing and marketing has to be done. Thus along with basic infrastructure factors such as new technologies, improved practices, access to veterinary services and for providing inputs the dairy extension services becomes a vital component.

While the ongoing transformation in Indian macro economy with surge in growth of non-farm economy, decreases proportion of population involved in agriculture. This necessitates understanding context in which smallholder dairy is operating and its response to structurally changing macroeconomic conditions.

\section{Methodology}

The study involved collection of comprehensive literature and review. This included a wide range of publications and literature such as scientific articles, annual reports and government policy statements relevant to dairy sector. The major findings of various literatures specific to changes in smallholder dairy were collated under the following categories and summed up for broader understanding.

\subsection{Contextual change for smallholder dairying in India}

\subsubsection{Market forces influencing smallholder dairy production}

The percentage of population becoming urban has increased and neared the $50 \%$ mark. Their demand has to be met to match with their food and nutrient requirements. In addition increased disposal income had resulted in shifting of food habits from cereal to animal based protein. The per capita consumption of animal based protein has increased from 5.3 to $6.9 \mathrm{~kg} /$ annum across India while in urban India it was 6.6 to $7.7 \mathrm{~kg}$ /annum (GOI, 2006). Thus growing urban population has a shift in preference towards animal origin protein (Kumar et al., 2011). Delgado et al. (1999) indicated that by 2020 the demand for dairy products will be 160 million tonnes every year. This situation promotes dairy production and emerging market may provide opportunity for millions of smallholder dairy farmers of India.

At the same time it is disheartening to note that population engaged in agriculture and allied sectors is fast reducing due to urbanization. It has reduced from 63 per cent to 56.6 per cent during the period 1983 to $2004-2005$ (Sengupta, 2009). The rural population of India has declined from 72.19 to 68.84 per cent in the period between 2000 and 2011 (Chandramouli, 2011). While in Tamil Nadu State the rural population has declined from 55.96 to 51.55 per cent during the same period. This growing migration poses a threat to agriculture in general and dairying in particular. Further the composition of per capita income from farm sector has declined from 72 per cent to 62 per cent while the non-farm, self-employment has increased from 7 to 20 per cent during 1999 - 2007 (Mkhize, 2013). The scenario necessitates policy makers to promote policy that encourage farmers to take up dairying and also to retain existing farmers.

\subsection{Changes in smallholder dairy sector}

\subsubsection{Changing profile of animal owners}

In India youth constitute a major proportion of the population (over 40 per cent). In the recent years it was noticed that youth had withdrawn from agriculture (Sharma \& Bhaduri, 2007). The recent observations (Rao et al., 2002; Ravikumar et al., 2007; Jodhka, 2012; Jothilakshmi et al., 2014) suggest that average age of livestock farmers were in increasing trend and participation of youth were limited. This may be attributed to increase of rural non-farm employment opportunities. Even 
though there is decline in participation of youth in farming activities at current growth rate of rural non-farm sector and manufacturing sector, the chances of absorption of majority of rural workforce seems to be slow in coming future (Mkhize, 2013). Thus considerable section of rural youth needs to depend upon farming for their economic activity. In addition increasing feminisation trends in livestock farming activities also noticed. Women participation has increased in breeding, healthcare management and marketing activities which was earlier in man's domain (Jothilakshmi et al., 2014). Above all there is declining value system on "Dairy husbandry" as an occupation among rural community and thus matrimonial arrangements becoming difficult if youths are retained in livestock / agriculture sector. These factors pose a threat to the growth of dairying and require policy support that would promote livestock farming in general and dairying in particular.

\subsubsection{Crop and dairy animal interaction}

The changing food consumption pattern coupled with urbanization has brought changes in crop husbandry sector of India. The cropping pattern is shifting from cereals to high value agriculture crops such as vegetables and fruits (Birthal et al., 2007). In addition to above diversification in cash crops such as cotton, oil seeds and other crops are also replacing the cereals (Bhalla \& Singh 2010). The government also in forefront responded to emerging market changes through various policy measures and schemes. The national horticulture mission was initiated as a part of high value agriculture which promoted cultivation of vegetables, fruits and export oriented crops (Mittal, 2007). The above changes in cropping pattern were driven through policies and market demands. Between 1967-68 to 2007-08 it was observed that cultivation pattern for major fodder crops like Groundnut, paddy, sorghum was negative (Kannan \& Sujata, 2011; Birthal \& Negi 2012). However, there was increase in cultivation of cash crops such as maize, blackgram, green gram, coconut, fruits and vegetables (Velavan \& Balaji, 2012). Their byproducts have lesser application for providing balanced feeding ration to dairy animals. A sharp decline in grazing lands across India (Birthal \& Negi 2012; GOI - Planning Commission, 2012) was also noticed. Recent study in Tamilnadu state shows only 36 per cent of dairy farmers were using crop residues and cultivation of fodder crops such Cumbu Napier which increased almost fifteen fold (Thirunavukkarasu et al., 2014). All these indicate that the cropping pattern changes are resulting in weakening of crop-animal interaction and dairying system becoming more intensive.

\subsubsection{Intensification in smallholder production}

In the last decade, dairy sector has adopted a tendency towards intensification. This structural change may have significant effects on farm efficiency and consequently on economics of farms. Milk is a cash crop for smallholder by converting low value forages and crop-residues with use of low cost family labour. Farming patterns are not likely to be the same as earlier (Mkhize, 2013) and changing. Capital intensive (moving from integrated framing system to intensive farming approach) with use of drudgery reducing machines (Chaff cutter, fodder cutting / harvester, milking machine, automatic drinkers, improved housing and irrigated system etc.) has been on arise. Further, genetic modifications for enhancing quality of breeds as well as fodder varieties were also on high impetus for enhancing overall productivity.

This increasing demand is expected to push up intensification in mixed / crop-livestock farming system (Delgado et al., 2001; Udo et al., 2011; Wright et al., 2011). In India intensification process takes in the form replacement of stock, purchase of feed, health and breeding services etc. Shift from traditional approach to moderate intensive systems of production through breaking of relationship with crop husbandry activities is being initiated and tried by farmers at a moderate level.

\subsubsection{Structural changes in milk processing and marketing}

In the context of new economic policies it is noticed that Anand Pattern of co-operatives established through Operation Flood have slowly deteriorated and exhibited poor performance since 1995. This scenario continues to exist in most states of India. This has resulted in distrust among the smallholder dairy producers. Further liberalization policy led to privatization of dairy sector through Milk and Milk Products Order 1992 (Now referred as Milk and Milk Products Amended Regulations Orders - MMPR-2009). After 2002 the milk shed concept (Privilege rights in procuring milk for the developing organisation involved developing smallholder dairying) was removed and licensing procedure was eased. This promoted privatization of the dairy sector to a large extend and resulted in development of private players over a period of time. Through this development, the procurement, processing and marketing by the private sector has increased when compared to dairy co-operatives. Private diary sector has evolved and over taken dairy co-operatives in procurement, processing and marketing in the year 2011-12. The growth of private sector in dairying had attracted investment from private equity funds which has invested 89.5 million US dollars in dairying during the period "May 2010 to November 2012" (Narasimhan, 2012). Thus it can be stated that MMRO has opened for private market players with a paradigmatic shift in milk processing, procurement and marketing. This has also facilitated private promoted vertical integration in dairy supply chain through contract farming.

\subsubsection{Changes in livestock service delivery system}

Livestock services play a key role in livestock production and in animal husbandry development. Generally livestock services were predominantly a public domain until 2000. But later on new economic policies slowly promoted the private participation over the years (Jothilakshmi et al., 2011). Privatisation of breeding services through the State Livestock Development Agency (TNLDA, APLDA, KLDA, etc) and its lay inseminators are a move in this direction. Andhra Pradesh 
has taken lead role in promoting lay inseminators (Gopal mitras) in privatisation of breeding services. In addition NGOs (such as Bharat Agro Industrial Federation-BAIF and JK trust) have taken stride to move away from the immobile veterinary dispensaries/hospitals based livestock services to mobility based services through para-veterinary staff and cost recovery mode. Various stake governments have outsourced selected livestock services to such NGOs. Further privatisation of breeding services has been promoted in World Bank funded watershed development and IAMWARM schemes in several of states. Similarly private milk procurement companies have also engaged in providing services to farmers through para vets and veterinarians at doorstep with a cost recovery. Similarly efforts of NABARD to develop agri-clinics are also an effort to increase coverage of private veterinary health care. Thus public sector is moving away from livestock sector is becoming dominant phenomena. Many of resource poor farmers were not able to pay for private and continue to prefer free public veterinary service provided by government. But in order reduce drudgery of taking animals to public service centres which are mostly immobile, farmer are forced to accept paid animal health care as it is delivered at their doorstep. In addition there is also a promotion of private sector participation in extension services. As a result growth of private extension service providers (Eg. Reuter's market light) who caters advisory services with a cost are noticed. Thus there is slow trend in change of service providers from public sector to private and from free service to paid services. Thus privatised services pose a concern over increasing cost of inputs and quality of services for dairying.

\section{Outlook of future dairy production in India}

Dairy sector is in primitive stage of development and modernisation though the country has large consumer base as well as major producer of dairy related products in the world. It is imperative to meet growing demand of dairy products, since there is a rise in purchasing power of growing population since 2000. While move to rural non-farm sector or urban sector has been primarily distress induced (Jatav \& Sen, 2013) to mitigate loss from agriculture and allied sectors. This may be accounted to market economic policies of government resulting in decline of support to agriculture, livestock and allied sector through budget allocation and subsides (Dev, 2011; Harish et al., 2011). Even though there is decline in participation of youth in farming activities at current growth rate of rural non-farm sector and manufacturing sector, the chances of absorption of rural workforce seems to be slow in the coming future (Mkhize, 2013). So dairy farming may be more of part time; in which women may be a leading force. In addition increasing market demand and emerging vacuum at production side is also attracting non-farm families and youth of quitted families' to an extent. Smallholder dairying is shifting from traditional to moderate intensive approach with increased capital, improved biological technologies (improved animals and fodder varieties) and mechanisation.
Emerging changes in milk processing, marketing; delivery of livestock services; changing profile of producers; crop-dairy animals interaction; urbanization; demand for milk and milk products and sets up pressure on at production levelnecessitates reworking on extension approaches. It is strongly recommended to have two fundamental strategies to meet out these new paradigms which include; reorienting the extension service delivery system and extension research to match the changes. The details of which are discussed below.

\section{Reorientation of dairy extension system to meet changes}

\subsection{Extension services delivery system}

Current dairy extension system comprises of state animal husbandry departments and their associated grass-root organizations and intermediate level structures, dairy cooperatives, private dairies, central and state government educational and research institutes, non-governmental organisation, input suppliers and freelance media (Thirunavukkarasu et al., 2008). The system was tuned during periods of operation flood in the context of cross breeding programme. This system needs to reorient to meet out the requirements of "high level of knowledge" for moderately intensive farming. Knowledge demands on "moderate intensive dairy system" can be met through starting of dairy polytechnics - offering diploma and degree programmes for farming youth; creating infrastructure to train youth with model farms, hygienic milk production, processing plants etc.

In addition to encouraging of new stakeholders namely private dairy players to carry out dairy extension services; rather than capitalising existing milk sheds developed through operational flood programmes. It necessitates inclusion of training and motivation of non-public sector para staff such as lay inseminators, community animal health workers etc., for dairy extension services. Also increasing the capacity of dairy extension staff on "know-how" in mechanisation, fodder production trends and other technological related issues, gender issues, building new institutional arrangements and youth retention strategies in the changing context would strengthen the dairy sector.

Diary extension system should play a wider role in promoting and sustaining dairy through new institutional arrangements such as dairy farming groups, associations, new generation cooperatives and farmers producer organisation. Networking of the above collectives with forward and backward linkages for input supply and marketing is to be done for facilitation of sustained production.

The long term strategies to sustain and enhance potential of new generation of farmers is to be done through building of institution which facilitate identification of potential markets, technology transfer, exchange of knowledge, financial linkages through channelizing private equity, venture capital funding, distribution, marketing and joint ventures. 
Research on dairy extension activities need to be strengthened with an emphasis on understanding the role of dairying in livelihood, food security, gender issues such as empowerment, feminisation and gender specific issues in technologies in the changing context of dairying. Similarly evolution of dairy farming system in response to poor participation of youth, changing cropping pattern, mechanisation, intensification of dairy farming, influence of new generation co-operatives and non-farm sector development on dairy

to be taken up farming have to be constantly researched for making development.

Research need on impact of reforms on livestock services and sector; institutions, institutional changes; issues and strategies in entrepreneurial development in livestock production; understanding institutions industry linkages; veterinary manpower planning; prospects of contract farming practices; extension strategies to meet out the challenges of climate change and environment concerns; identification, assessment and refinement of grass root technologies and research delivery pathways. But this reorientation of dairy extension services and research may not be complete panacea for sustainability when in Asia, as majority increase in livestock produce originates from industrialized orientation of production system (Thirunavukkarasu et al., 2014; FAO, 2016)

\section{Conclusions}

The increasing market demand for milk, entry of private processing industries, increasing role of non-farm in economy, poor participation of youth in agriculture, policy changes are influencing smallholder dairy and transformation is noticed. This demands use of farmers collectives as a contact point for extension agent, capitalizing information technology potential for delivery of services, making mandate for processors to do extension servicers etc. Further research in extension science needs to be directed towards understanding ongoing changes in farming and evolve suitable strategies to restructure the dairy extension system and develop new innovations in technology dissemination.

Note: Improvised version of a lead paper presented to IDA conference 2013 - "Indian Dairying: Growth and Trade Issues, held on 12-14 December, 2013, Chennai.

\section{Conflict of interest}

Authors would hereby like to declare that there is no conflict of interests that could possibly arise.

\section{References}

Bhalla GS, Singh G (2010) Growth of Indian Agriculture: District Level study. Centre for Study of Regional Development, Jawaharlal Nehru University, New Delhi. Available 04.pdf retrieved on 27 May 2014.

Mkhize BHP (2013) The stunted structural transformation of the Indian economy. Agriculture, Manufacturing and the Rural Non farm sector. Economic Political Weekly 48 :5-12.

Birthal PS, Joshi PK, Roy D, Thorat A (2007) Diversification in Indian agriculture towards high-value crops. Discussion Paper 00727. International Food Policy Research Institute, Washington DC, USA. Available on www.ifpri.org/sites/default/files/publications/ifpridp00727.pdf retrieved on 27 May 2014.

Birthal PS, Negi DS (2012). Livestock for higher, sustainable and inclusive agricultural growth. Economic Political Weekly Supplement $47: 89-99$.

Chandramouli (2011) Census of India 2011, Rural Urban distribution of Population. Census India. Available on http://censusindia.gov.in/2011-prov/ results/paper2/data_files/india/Rural_Urban_2011.pdf retrieved on 27 May 2014.

Delgado C, Rosegrant M, Steinfeld H, Ehui S, Courbis C (1999) Livestock to 2020: the next food revolution. Food, Agriculture and the Environment Discussion paper 28. IFPRI/FAO/ILRI, Washington, DC, USA. Available on www.fao.org/ag/againfo/resources/documents/lvst2020/20201. pdf retrieved on 27 May 2014.

Delgado C, Rosegrant M, Steinfeld H, Ehui S, Courbois C (2001) Livestock to 2020: the next food revolution. Outlook Agriculture $30: 27-29$.

Dev M (2011) A note on trends in public investment in India. IGIDR proceedings / projects series PP-069-SMD2. Indira Gandhi Institute for Development Research, Mumbai. Available on http://www.igidr.ac.in/newspdf/srijit/PP-069SMD2.pdf retrieved on 27 May 2014.

FAO (2016) Pollution from industrialized livestock production, In. FAO Livestock Policy Briefs Facing the opportunities and challenges of the livestock sector, The Livestock Policy Briefs series, Livestock Information, Sector Analysis and Policy Branch (AGAL) of the Animal Production and Health Division, Food and Agriculture Organization, Rome, Italy. http://www.fao.org/3/aa0261e.pdf/www.fao.org/ag/aga.html.

GOI (2006) Livestock ownership across operational land holding classes in India, 2002-03, Report No. 493(59/18.1/1). New Delhi: National sample survey organisation, Ministry of Statistics and Programme implementation.

Harish M, Balachandran G, Pandit VN (2011) Public investment in Agricultural and GDP growth: Another look at the inter sectoral linkages and policy implications. Centre for 
Developmental Economics, Department of Economics, Delhi School of economics. Available on http://www.cdedse.org/pdf/work201.pdf retrieved on 27 May 2014.

Jatav M, Sen S (2013) Drivers of Nonfarm employment in Rural India-Evidence from 2009-10 NSSO round. Economic Political Weekly 48 : 13-21.

Jodhka SS (2012) Agrarian changes in the times of (Neo liberal) 'crises' -Revisiting attached labour in Haryana. Economic political weekly (supplement) $47: 5-13$.

Jothilakshmi M, Thirunavukkarasu D, Sudeepkumar NK (2011) Structural changes in livestock service delivery system - A case study of India. Asian Journal of Agricultural Research 5 : 98-108. DOI: 10.3923/ajar.2011.98.108.

Jothilakshmi M, Thirunavukkarasu D, Sudeepkumar NK (2014) Exit of youths and feminization of smallholder livestock production-a field study in India. Renewable Agriculture and Food Systems 29 :146-150. doi:10.1017/S174217051300001X.

Kannan E, Sujata S (2011) Analysis of Trends in India's Agricultural Growth. Working Paper, 276. The Institute for Social and Economic Change, Bangalore. Available on http://www.isec.ac.in/WP\%20276\%20-

\%20Elumalai\%20Kannan_1.pdf retrieved on 27 May 2014.

Kumar A, Rai DC, Choudhary KR (2011) Prospects and opportunities for exports of dairy products from India. Indian Journal of Animal Sciences 81 :86-91.

Narasimhan TE (2012) Dairy sector becomes a sweet spot for PE funds. Available on http://www.businessstandard.com/article/companies/dairy-sector-becomes-a-sweetspot-for-pe-funds-112121300209_1.html retrieved on 02 May 2013.

GOI - Planning Commission (2012) Report of the working group on Animal Husbandry and Dairying, $12^{\text {th }}$ Five year plan. http://planningcommission.nic.in/aboutus/committee/wrkgrp12 /agri/AHD_REPORT_Final_rev.pdf retrieved on 23 April 2014.

Rao SVN, Ramkumar S, Waldie K (2002) Dairy Farming by Landless Women in Southern States of India. Proceedings of the International Workshop Livestock Services and the Poor. pp 73-86. Oct 28-29, 2002. Bhubaneswar, India.
Ravikumar S, Reddy KVR, Rao BS (2007) Farmers' choice for cost recovery of veterinary services in different livestock holding systems- A case study of India. Livestock Research for Rural Development 19 . Available on http://www.lrrd.org/lrrd19/5/kuma19066.htm retrieved on 27 May 2014.

Sharma A, Bhaduri A (2007) The "Tipping Point" in Indian Agriculture: Understanding the Withdrawal of the Indian Rural Youth. Asian Journal of Agriculture and Development 6 :115130.

Sengupta KA (2009) The challenge of employment in India. In Report of National commission for enterprise in unorganized sector, Government of India, New Delhi; Academic foundation.

Mittal S (2007) Can horticulture be a success story for India? Working paper No 197. Indian council for research on International economic relations, New Delhi, India. Available on www.icrier.org/pdf/Working_Paper197.pdf retrieved on 27 May 2014.

Thirunavukkarasu D, Thorne P, Balaji V, Bezkorowajnyj PG, Romney D (2008) Dairy toolbox and its relevance to Indian dairy extension system. Proceedings of International conference on Social science perspectives in agricultural Research and development. 15-18 Feb 2006. New Delhi, India, Pp 505-519..

Thirunavukkarasu D, Jothilakshmi M, Murugesan S, Doraisamy KA (2014) Transition of smallholder dairy farming system - a micro study in Tamil Nadu, India. Livestock Research for Rural Development 26(5) retrieved August 9, 2014, from http://www.lrrd.org/lrrd26/5/thir26088.html

Udo HMJ, Aklilu HA, Phong LT, Bosma RH, Budisatria IGS, Patil BR, Samdup T, Bebe BO (2011) Impact of intensification of different types of livestock production in smallholder croplivestock systems. Livestock Science 139 :22-29.

Velavan C, Balaji P (2012) Crop diversification in Tamil Nadu-A Temporal Analysis. Agricultural Situation in India 78 : 655-658.

Wright IA, Tarawali S, Blummel M, Gerard B, Teufel N, Herrero M (2012) Integrating crops and livestock in subtropical agricultural systems. Journal of the Science of Food and Agriculture 92 : 1010-1015. doi: http://dx.doi.org/10.1002/jsfa.4556. 